\title{
Intercropping of taro and sunn hemp with cutting periods during the cycle ${ }^{1}$
}

\author{
João Nacir Colombo ${ }^{2 *}$, Mário Puiatti, Jaime Barros da Silva Filho ${ }^{3}$, Ricardo Henrique Silva Santos ${ }^{3}$, \\ Luiz Antônio dos Santos Dias ${ }^{3}$ \\ 10.1590/0034-737X201865010006
}

\begin{abstract}
Intercropping using legumes is one of the ways to protect the main crop, and in long term improve the physical and chemical properties of the soil. The aim of this work was to evaluate the intercropping of Colocasia esculenta (L.) Schott (taro) and the tropical legume Crotalaria juncea L. (sunn hemp), cutting sunn hemp at ten periods during the cycle. The experiment was carried out under field conditions between 09/23/2010 and 06/04/2011. It consisted of 11 treatments related to the 10 cutting times of sunn hemp $(55,70,85,100,115,130,145,160,190$, and 220 days after sowing - DAS) plus a control of taro with no sunn hemp. During the cycle, taro was evaluated for plant height and incidence of leaf burn. At the time of cutting the sunn hemp, the plant height, fresh and dry matter masses, and nutrient content of the biomass were calculated. During taro harvest, we evaluated the productivity of the mother rhizomes and classified the cormels. Taro plants shaded by sunn hemp showed a lower incidence of leaf burn. The sunn hemp cut from 145 DAS onwards affected the yield of comercial rhizomes and total and agroeconomic indexes. Sunn hemp cut up to 130 DAS provided better performance of taro, without compromising productivity and economic indicators, with the highest amounts of $\mathrm{N}$ and $\mathrm{K}$ observed in the biomass cut at 115 DAS.
\end{abstract}

Key words: Colocasia esculenta (L.) Schott; Crotalaria juncea L.; production; management.

\section{RESUMO}

\section{Consórcio taro com crotalaria com períodos de corte durante o ciclo}

A consorciação com leguminosas é uma prática que permite proteger a cultura e no longo prazo promover melhoria das condições físicas e químicas do solo. O objetivo do trabalho foi avaliar o consórcio taro (Colocasia esculenta (L.) Schott) com crotalaria (Crotalaria juncea L.) com o corte da crotalaria em 10 épocas durante o ciclo. O experimento foi conduzido a campo entre 23/09/2010 a 04/06/2011. Consistiu de 11 tratamentos referentes a 10 épocas de corte da crotalaria $(55,70,85,100,115,130,145,160,190$ e 220 dias após a semeadura - DAS), mais o taro solteiro (controle). Durante o ciclo, foi avaliada a altura de planta e incidência da queima de folhas do taro. No momento do corte da crotalaria foram calculados a altura de planta, massas de matéria fresca e seca e teor de nutrientes da biomassa. Durante a colheita do taro, foi avaliada a produtividade de rizomas mãe e das classes de rizomas filhos. As plantas de taro sombreadas pela crotalaria apresentaram menor incidência de queima das folhas. O corte da crotalaria a partir dos 145 DAS afetou a produtividade de rizomas comerciais e total e índices agroeconômicos. O corte da crotalaria até 130 DAS proporcionou melhor desempenho do taro, sem comprometer a produtividade e indicadores econômicos, com as maiores quantidades de $\mathrm{N}$ e K observadas na biomassa cortada aos 115 DAS.

Palavras-chave: Colocasia esculenta (L.) Schott; Crotalaria juncea L.; produção; manejo.

\footnotetext{
Submitted on February $29^{\text {th }}, 2016$ and accepted on December $1^{s t}, 2017$.

'This work is part of the first author's doctoral thesis.

${ }^{2}$ Instituto Federal do Espírito Santo, Campus Santa Teresa, Santa Teresa, Espírito Santo, Brazil. joaonacirc@yahoo.com.br

${ }^{3}$ Universidade Federal de Viçosa, Departmento de Agronomia, Viçosa, Minas Gerais, Brazil. mpuiatti@ufv.br; jaimeufv@gmail.com; rsantos@ufv.br; lasdias@ufv.br

* Correspondence author: joaonacirc@yahoo.com.br
} 


\section{INTRODUCTION}

The taro plant (Colocasia esculenta L. Schott) is considered as the main vegetable of the family Araceae. In some regions, such as in South-Central Brazil, it is called "inhame" and often confused with the species Dioscorea alata L., also known as "cará". According to Pedralli et al. (2002), after the first national symposium on inhame and cará cultivation (held in Venda Nova do Emigrante, EspiritoSanto, Brazil in 2001), a new nomenclature was established, in which Colocasia esculenta was given the definitive name of "taro" and dioscoreáceas (Dioscorea spp.) are now known as "inhame."

The species is native to Asia and currently ranks fourth among the tropical tubers harvested in the world with respect to volume produced. In Brazil, production is concentrated in the southeast region, which was responsible for supplying $94 \%$ of this product in the country between 2008 and 2013 (Conab, 2014). In hotter regions of the country, the crop can be cultivated all year round and the cultural cycle is about seven months; in the southeastern region of Brazil, the cultural cycle is about nine months (Puiatti, 2002). Because taro is a longcycle vegetable, its cultivation becomes viable in the form of a consortium with other crops.

The use of leguminous cover crop plants with increased green mass is a good alternative method for prevention of soil degradation, as legumes improve soil fertility (Santos et al., 2013). One of the most significant aspects of such an association is the possibility of increasing the $\mathrm{N}$ availability for the main crop after the legume is cut.

For any plant consortium to be successful, the selection of the intercrop species is critical. Sunn hemp (Crotalaria juncea) is an annual legume characterized by an erect stem, rapid growth, and short growth cycle (ranging between 120 and 150 days). It shows substantial biomass content with appreciable ability to fix $\mathrm{N}_{2}$ and recycle the various constituents of the soil nutrient profile. The legume has almost no pest-related problems and/or diseases (Souza \& Resende, 2006) and is, therefore, suitable for growing in a consortium with other species.

Besides the species selected and the planting season, spatial arrangement and green manure management are also important aspects that contribute to the success of a crop consortium. Thus, green manure management and main crop management - in that order - reduce the competition for light, water, and nutrients. They also increase the efficiency of the synchronization between nutrient mineralization by the green manure mass and the absorption of these nutrients by the crops (Silva \& Menezes, 2007).
A study by Oliveira et al. (2004) focused on the involvement of the taro consortium with sunn hemp and demonstrated its ability to produce significant amounts of $\mathrm{N}$ in the plant biomass. The taro and sunn hemp consortium also promotes nutrient cycling and shows a large increase in the organic matter due to the high dry matter content after pruning (Silva et al., 2006; Oliveira et al., 2007). This does not compromise the productivity of the commercial rhizomes produced by taro (Oliveira et al., 2007).

Taro plantations in Rio de Janeiro (Recope - RJ, 1999) and Minas Gerais states (Puiatti, 2002) are often affected by extensive leaf burn due to exposure to direct sunlight. As these injuries from the sun rays result in the reduction of leaf area, there is a consequent decrease in the production of the assimilates, which may affect the rhizome development. Leaf blight reduction by shading is another benefit provided by the taro and sunn hemp consortium (Oliveira et al., 2004; 2007).

Several research studies have revealed the possibility of intercropping vegetables with green manure, such as broccoli with velvet bean (Siqueira et al., 2009), taro with pigeon pea (Oliveira et al., 2006), taro with dwarf velvet bean, and Crotalaria spectabilis Roth (Tivelli et al., 2013) with sunn hemp (Oliveira et al., 2004; Silva et al., 2006; Oliveira et al., 2007). However, these studies were performed with the vegetables being cultivated in the interim form and banded with green manure. Co-cultures in the same planting row were not investigated. Interim cultivation has difficulties with respect to crop management and, depending on the arrangement, loss of the taro population resulting in yield reduction.

Therefore, this study aimed at evaluating the performance of taro and sunn hemp grown in the same row of planting, with variation in the cutting times of sunn hemp during the crop cycle.

\section{MATERIAL AND METHODS}

The experiment was conducted from 9/23/2010 to 6/4/ 2011 under field conditions. The red-yellow Argisol Cambic soil in this study exhibited the following chemical characteristics at $0-20 \mathrm{~cm}$ of depth: $\mathrm{pH}\left(\mathrm{H}_{2} \mathrm{O}\right)=5.6 ; \mathrm{K}^{+}=$ $76.0 \mathrm{mg} \mathrm{dm}{ }^{-3} ; \mathrm{P}=57.9 \mathrm{mg} \mathrm{dm}{ }^{-3} ; \mathrm{Ca}^{2+}=2.8 \mathrm{cmol}_{\mathrm{c}} \mathrm{dm}^{-3} ; \mathrm{Mg}^{2+}$ $=0.5 \mathrm{cmol}_{\mathrm{c}} \mathrm{dm}^{-3} ; \mathrm{Al}^{3+}=0.0 \mathrm{cmol}_{\mathrm{c}} \mathrm{dm}^{-3} ; \mathrm{H}+\mathrm{Al}=3.47 \mathrm{cmol}_{\mathrm{c}}$ $\left.\mathrm{dm}^{-3} ; \mathrm{SB}=3.49 \mathrm{cmol}_{\mathrm{c}} \mathrm{dm}^{-3} ; \mathrm{CEC}_{\mathrm{T}}\right)=6.96 \mathrm{cmol}_{\mathrm{c}} \mathrm{dm}^{-3} ; \mathrm{V}=$ $50 \%$; organic matter $=2.7 \mathrm{dag} \mathrm{kg}^{-1} ; \mathrm{P}_{\text {rem }}=35.9 \mathrm{mg} \mathrm{L}^{-1} ; \mathrm{Zn}$ $=10.4 \mathrm{mg} \mathrm{dm}^{-3} ; \mathrm{Fe}=37.7 \mathrm{mg} \mathrm{dm}^{-3} ; \mathrm{Mn}=78.1 \mathrm{mg} \mathrm{dm}^{-3} ; \mathrm{Cu}$ $=2.1 \mathrm{mg} \mathrm{dm}^{-3}$; and $\mathrm{B}=0.2 \mathrm{mg} \mathrm{dm}^{-3}$. The physical analysis of soil textural class showed $28 \%$ sand, $17 \%$ silt, and $55 \%$ clay. As this area was used to cultivate vegetables, based on the chemical and physical analyses recommended for 
the taro crop, neither soil amendment nor fertilizer application with macro- and micronutrients was required.

The experiment was conducted in a randomized complete block design, with four replications. It included 11 treatments, corresponding to the taro monoculture (control) and 10 periods of consortium before cutting (55, $70,85,100,115,130,145,160,190$, and 220 days after sowing; DAS) of sunn hemp.

The plot consisted of four rows, each of $3.0 \mathrm{~m}$ long and spaced $1.0 \mathrm{~m}$ apart. Each row contained ten taro plants spaced at $0.30 \mathrm{~m}$. In the intercropping area, sunn hemp was sown at $10 \mathrm{~cm}$ from the taro line, with 40 seeds sowed per meter. Thinning was performed $15 \mathrm{DAS}$, leaving only 20 plants per meter. The net area consisted of a $4.0 \mathrm{~m}^{2}$ area with its borders set at $0.5 \mathrm{~m}$ from each row of taro and each border of the plot.

Taro was planted on 9/23/2010. Clones of the taro corms BGH 5925 ('Japanese') were used as seedlings. Weighing about $60 \mathrm{~g}$ on average, the corms were sowed in 12-cmdeep grooves. Sunn hemp was sowed on 10/26/2010 in grooves at a depth of $2 \mathrm{~cm}$, open laterally to the taro line. Weeding was performed thrice in all the plots up to 30 DAS of sunn hemp. Irrigation, whenever necessary, was done using the conventional sprinkler.

At each cutting time, sunn hemp was cut close to the ground; weighing was done to obtain the fresh weight, after which a representative plant sample containing about $0.5 \mathrm{~kg}$ of the fresh material cut from each plot was minced and oven-dried using forced-air at $70{ }^{\circ} \mathrm{C}$, until constant weight was achieved. After drying, it was weighed again to calculate the dry weight. The dried material was then ground using a Wiley mill and analyzed to determine the nutrient content. All the remaining sunn hemp cuttings were placed laterally to the taro plants in the range of about $0.60 \mathrm{~m}$ width.

When sunn hemp was cut, the height of the taro plants (soil level until the insertion of the petiole in the leaf blade) was measured in three plants representative of the two central rows of each plot. The length of the cut sunn hemp plants was measured in six plants representative of the two central rows of each plot.

When sunn hemp reached 130 DAS (163 days after planting DAP taro), the incidence of radiation-induced leaf burn in the taro plants was assessed. This was estimated by the percentage of the injured area according to the diagrammatic method described by Michereff et al. (2000) modified as follows: diseased leaf area (\%) of 1 to 3, 3 to 6,6 to 12,12 to 25,25 to 50 and $>50 \%$, were respectively denoted as 1, 2, 3, 4, 5, and 6 .

Once taro reached maturity at $225 \mathrm{DAP}$, six plants were removed from the soil of each plot. The fresh weight and number/class of the cormels (daughter rhizomes) were evaluated. The cormels were classified based on their transverse diameter, according to Puiatti et al. (2000) as follows: great ( $>47 \mathrm{~mm})$, middle $(40-47 \mathrm{~mm})$, small $(33-40$ $\mathrm{mm})$, and waste $(<33 \mathrm{~mm})$. The sum of classes of the great, medium, and small cormels were considered marketable.

Using the production data of the rhizomes and the trading price, we evaluated the economic efficiency of the intercropping systems using the following agroeconomic indicators (indexes): land use efficiency index (LUE), gross income (GI), net income (NI), monetary advantage (MA), corrected monetary advantage (CMA), rate of return (RR), and profitability index (PI).

The LUE index consortium was calculated using the following expression: $\mathrm{LUE}=(\mathrm{Ptc} / \mathrm{Pts})$, in which Ptc is the taro crop yield in the consortium with sunn hemp and Pts is the productivity of the single taro crop (monoculture). The average nominal wholesale price in June 2011 (harvest month) used to calculate the GI was obtained from the major regional produce distribution center, CEASA-MG in Contagem, Minas Gerais State (CEASA-MG, 2011). The mother and waste rhizomes were not included in this calculation.

The NI was calculated as the difference between the gross income and total operating costs (TOC). The TOC in both cropping systems were estimated from the technical coefficients for taro production costs submitted by Puiatti (2002), with modifications based on the requirements of the operations and inputs presented in the experiment. The costs of inputs, services, packaging, and transport were calculated from the prices in Viçosa - Minas Gerais, Brazil, from September/2010 to June/2011.

The MA and CMA were calculated using the following expressions: $\mathrm{MA}=\mathrm{GI} \times(\mathrm{LUE}-1) / \mathrm{LUE}$ and $\mathrm{CMA}=\mathrm{NI} \times$ LUE - 1)/LUE. The RR per dollar invested in each treatment was obtained through the relationship between the gross income and the cost of production. The PI was obtained from the relationship between the NI and GI and expressed as a percentage, according to Oliveira et al. (2005) and Cecílio Filho et al. (2008).

The data were subjected to analysis of variance for each harvesting date and compared to the control using Dunnett's test $(p<0.05)$. Average values by treatment were grouped by the Scott-Knott criterion $(p<0.05)$.

Treatments were screened for their effect(s) on fresh and dry masses and were measured only for $C$. juncea. Plant height was measured for C. esculenta and $C$. juncea. Models were chosen based on biological relevance. The significance of regression coefficients was determined using the $\mathrm{t}$ test, adopting the $10 \%$ level of probability and the coefficient of determination $\left(\mathrm{R}^{2}=\frac{S S_{\text {Regression }}}{S S_{\text {Treatement }}}\right)$. 


\section{RESULTS AND DISCUSSION}

\section{Plant growth}

The height of taro plants in the consortium with sunn hemp ranged from 0.92 to $1.80 \mathrm{~m}$, with the highest value achieved in the cut done at 115 DAS (148 DAP taro). Sunn hemp ranged in length from 1.48 to $3.52 \mathrm{~m}$, with the highest value observed at 190 DAS (Figure 1).

The height values of taro plants in the intercropping system observed in this study were higher than those recorded by Gondim et al. (2007) in the same soil conditions. They recorded a value of $151.8 \mathrm{~cm}$ at 139 DAP taro ('Japanese') grown under conditions of $50 \%$ shading. It should be noted that the height of sunn hemp in the cut at 115 DAS was $3.16 \mathrm{~m}$, which may have represented shading of taro plants above $50 \%$. Light restriction stimulates the leaf petiole elongation in taro plants in search of greater sunlight capture (Gondim et al., 2007; 2008).

In this study, the growth of taro shoots occurs until approximately 115 DAS of sunn hemp (148 DAP taro). In fact, Puiatti et al. (1992) verified the accumulation of dry mass in 'Japanese' taro leaves up to 165 DAP and, later, the process of foliar senescence with photoassimilate translocation to the reserve organs occurred. The consortium system possibly had no effect on the phenological stages of taro, as the minor differences in relation to the work could be due to the planting season and edaphoclimatic factors.

Regarding sunn hemp, the greatest length was found higher than the 1.80 m observed by Oliveira et al. (2004)

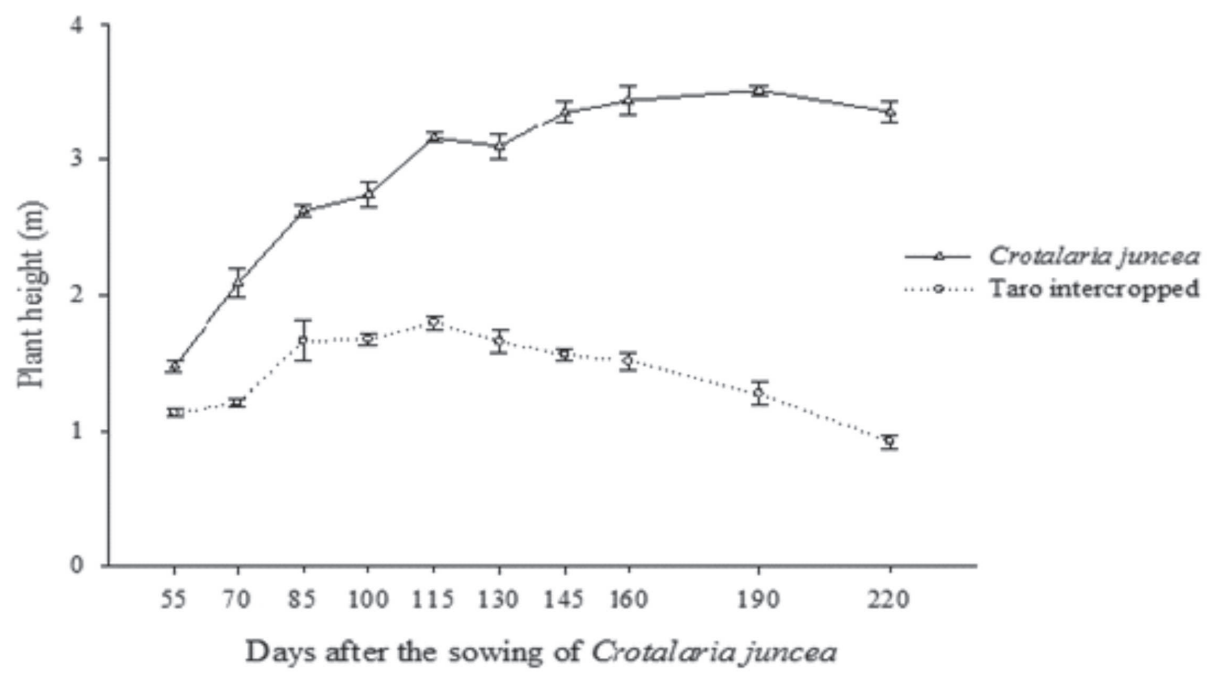

Data are presented as means \pm standard error $(n=4)$.

Figure 1: Height of the taro and C. juncea plants recorded during the respective cutting periods of the sunn hemp.

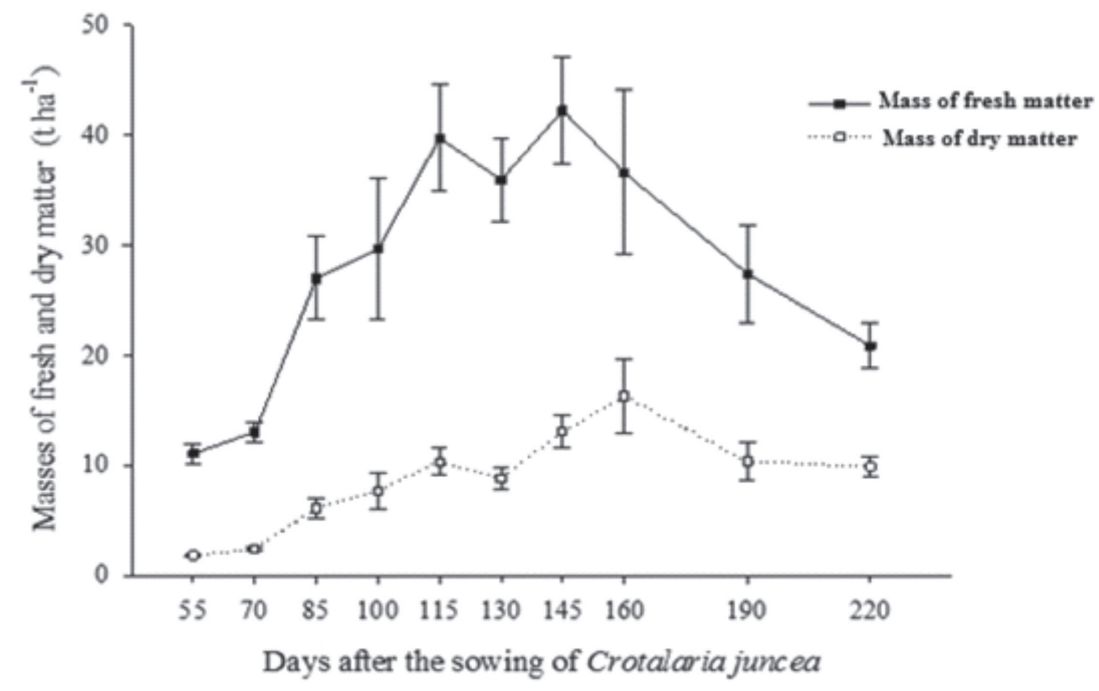

Data are presented as means \pm standard error $(n=4)$.

Figure 2: Masses of fresh and dry matter of the sunn hemp (Crotalaria juncea) plants observed at their dates of cutting. 
in the consortium with taro 'Chinese' variety intercropped without pruning in Nova Friburgo - RJ, Brazil, with 0.50$\mathrm{m}$ spacing between rows. It is possible that the greater spacing employed in that study may have provided greater plant vigor in sunn hemp with greater shoot development.

The fresh and dry masses of sunn hemp resulting from the cuttings ranged from 11.06-42.23 to1.82-16.82 $\mathrm{tha}^{-1}$, respectively. The maximum values of the fresh biomass were observed at 145 DAS in sunn hemp, while for dry matter, the highest values were observed at 160 DAS (Figure 2).

No other studies were identified in the literature in which sunn hemp was cut up to 160 DAS. Silva et al. (2006) reported values corresponding to $4.5 \mathrm{t} \mathrm{ha}^{-1}$ of dry matter at 60 DAS, corresponding to the findings in this work; however, it must be pointed out that the spacing of $0.50 \mathrm{~m}$ between rows in that study featured twice the plant density. Oliveira et al. (2007) reported values of 6.85 tha ${ }^{1}$ at 120 DAS, which are lower than those found in this study, utilizing the same plant density.

\section{Nutrient quantity present in the sunn hemp biomass}

The nutrient quantity present in the cut sunn hemp mass varied with the cutting times, forming mean groups for each nutrient (Table 1). The treatments that gave the highest average values for $\mathrm{N}, \mathrm{K}, \mathrm{Ca}, \mathrm{S}, \mathrm{Zn}$, and $\mathrm{B}$ were cutting sunn hemp at 115 and 160 DAS.

We observed lesser amounts of nutrients in the first two cutting times, a fact which is assumed to be due to the smaller amount of mass being produced by the plants in the initial growth phase. At 85 DAS, an increase was observed in most nutrients due to higher aggregate mass by the plants, especially after the cutting at 100 DAS. This was especially evident for $\mathrm{N}, \mathrm{K}$, and B, which formed group means distinct from the other nutrients, with higher values for the earlier cuts.

This study revealed that the quantities of $\mathrm{N}, \mathrm{K}, \mathrm{Zn}$, $\mathrm{Cu}$, and $\mathrm{B}$ found in sunn hemp were lesser than those observed by Puiatti et al. (2015). However, the amounts of $\mathrm{Mn}, \mathrm{Fe}, \mathrm{S}, \mathrm{Mg}$, and $\mathrm{Ca}$ were higher using the same plant density.

\section{Leaf burn}

In assessing the incidence of leaf burn in the taro leaves at 130 DAS of sunn hemp (163 DAP taro), we recorded two groups of averages: one in which the plants had already been cut (including the control and treatment of cutting at 130 DAS) with higher leaf damage and the group of plants yet to be cut (DAS 145 onwards), which had lower incidences of leaf burn that statistically differed from that of the control (Table 2).

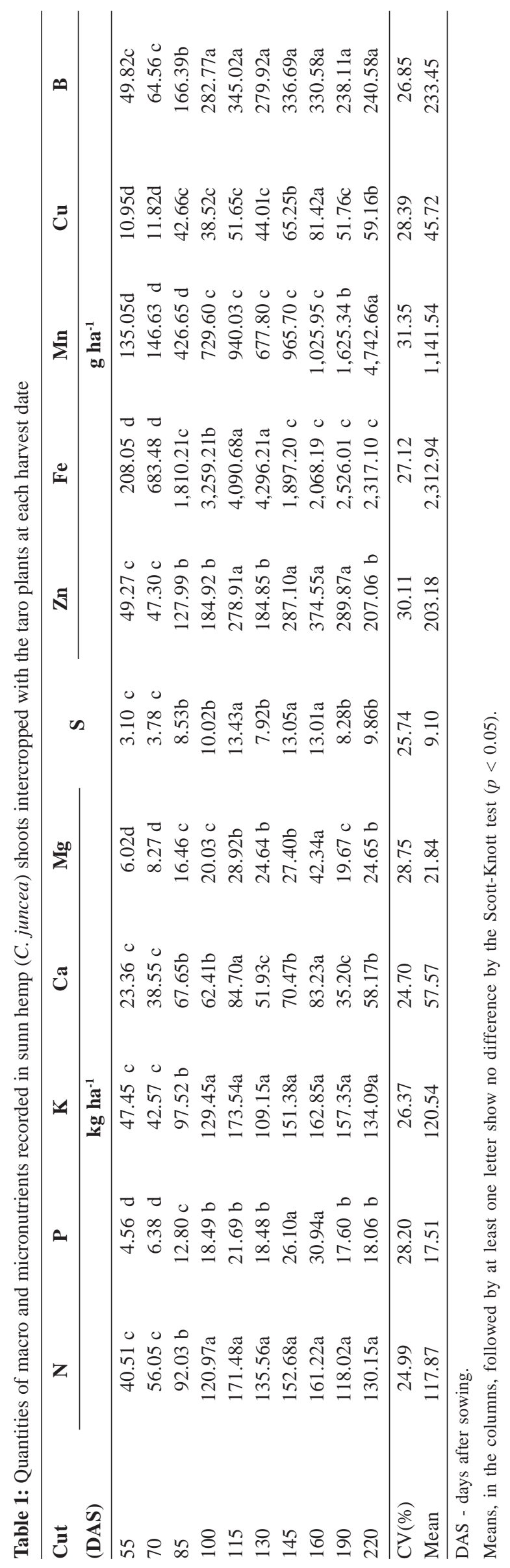

Rev. Ceres, Viçosa, v. 65, n.1, p. 035-043, jan/fev, 2018 
Soon after cutting was done, sunn hemp showed an increase in the incidence of leaf burn as the shading was abruptly removed and the taro leaves, which are sensitive to solar radiation and are grown in shade, were exposed to the full sunlight. A similar phenomenon was observed by Puiatti et al. (2000) in taro and sweet corn after the corn plants were removed. Taro was subjected to shading with Sombrite ${ }^{\circledR}$ meshes at 18 , 30, and $50 \%$ shading after the removal of meshes corn, and it resulted in a reduction of the leaf area (Gondim et al., 2007).

The presence of sunn hemp after the cutting treatment at $130 \mathrm{DAS}$ resulted in a reduced incidence of leaf burn in the taro leaves. Oliveira et al. (2007) also found that the cultivation of taro with $C$. juncea, in the intermediate stage (planted in alternate rows), reduced the intensity of leaf blight caused by solar radiation in the city of Nova Friburgo - RJ, Brazil. A study conducted in Magé - RJ, Brazil, by Oliveira et al. (2004), demonstrated a $100 \%$ reduction in leaf burn up until the fifth month of the crop cycle. In the eighth month, the shading continued to protect the plants, although less efficiently.

Taro leaves in the tropics experience necrosis during summer (Puiatti et al., 2000; 2002; Oliveira et al., 2004) caused by the photo-oxidation of chlorophyll due to excess incident radiation (Taiz \& Zeiger, 2010). These lesions can cause a reduction in the photosynthetic area (Gondim et al., 2007) and, therefore, productivity loss. In taro, the soluble sugars (the reducing ones, in particular) synthesized in the leaf get translocated to the rhizomes after undergoing "temporary storage" in the petiole (Hashad et al., 1956). Thus, any morphophysiological changes can affect the synthesis and translocation of the quantity of sugar during the rhizomes growth, thus influencing productivity. Therefore, under conditions of high solar radiation, the taro and sunn hemp consortium may reduce the incidence of leaf burn, thus providing conditions for optimal rhizome development.

\section{Taro production}

For taro, the average yield of commercial rhizomes, total rhizomes, and number of commercial rhizomes/plant shoots formed two groups (Scott-Knott). Crotalaria juncea cut after 130 DAS showed lower production than that of the group formed by the remaining treatments and the control (Table 3).
For the production of "large" daughter rhizomes, the means of the treatment group in which sunn hemp was cut at 145 DAS and underwent further cutting treatments at 55 and 115 DAS showed a decrease relative to the other treatments. Compared with the control, only the cutting treatments at 160 and 220 DAS revealed lower yields of large rhizomes. Regarding the number of large daughter rhizomes per plant, two group means were formed in which the sunn hemp that underwent cutting treatments at 85 , $115,145,160$, and 220 DAS were found to be lower than the other treatments, but not different from the control (Table 3).

The taro and sunn hemp consortium did not significantly affect the productivity of mother rhizomes. Oliveira et al. (2007) also observed no change in the productivity of the mother corm when sunn hemp was intercropped with taro during the entire cycle, even when it was pruned up to 120 DAS.

In general, the yield and number of rhizomes in the large class revealed a similar pattern, in which the plants grown in a consortium with the taro for a period of more than 130 DAS showed a decrease relative to the control. Silva et al. (2006) also showed lower productivity in the larger classes of rhizomes when sunn hemp was grown in double rows with $0.50 \mathrm{~m}$ spacing between the rows of taro. In that research, sunn hemp was sown at 90 DAP of taro and cutting was done at 60 DAS when the plants grew to an average of $2.50 \mathrm{~m}$ high. The reduction in the productivity of the largest rhizome classes is not beneficial, as it is of higher value (Puiatti, 2002).

The reduction in the mass and number of commercial cormels per plant was also reported by Oliveira et al. (2007) when sunn hemp was not cut. However, Oliveira et al. (2004) reported no decrease in the yield of commercial cormels when this crop was sown at 60 DAP with taro and maintained when intercropped with taro. Silva et al. (2006) also did not observe any effect on the commercial rhizomes when sunn hemp was left uncut.

Despite the high amounts of nutrients inserted by sunn hemp after the cutting at 100 DAS (Table 1), the cutting treatments done with sunn hemp at 130 DAS resulted in lower values for commercial cormels, total cormels, and total yield of the rhizomes (Table 3). The sunn hemp mass obtained from the cuts done at 145 and 160 DAS showed

Table 2: Leaf burn incidence in the taro leaves measured at 130 DAS of sunn hemp (C. juncea) (163 DAP taro) in the monoculture treatment of taro (control) and the taro and sunn hemp consortia cut at different times, in days after sowing (DAS)

\begin{tabular}{|c|c|c|c|c|c|c|c|c|c|c|c|c|}
\hline $\begin{array}{l}\text { Cut } \\
\text { (DAS) }\end{array}$ & Cont. & 55 & 70 & 85 & 100 & 115 & 130 & 145 & 160 & 190 & 220 & $\operatorname{CV}(\%)$ \\
\hline Notes & $3.25 \mathrm{a}$ & $3.25 \mathrm{a}$ & $3.00 \mathrm{a}$ & $3.75 \mathrm{a}$ & $3.00 \mathrm{a}$ & $3.25 \mathrm{a}$ & $3.75 \mathrm{a}$ & $1.00 b^{*}$ & $1.00 b^{*}$ & $1.25 b^{*}$ & $1.25 b^{*}$ & 39.28 \\
\hline
\end{tabular}

Means, in the lines, followed by the same letter, do not differ by the Scott-Knott test $(p<0.05)$; the medium followed by an asterisk $(*)$ differs from the control by Dunnett's test $(p<0.05)$. 


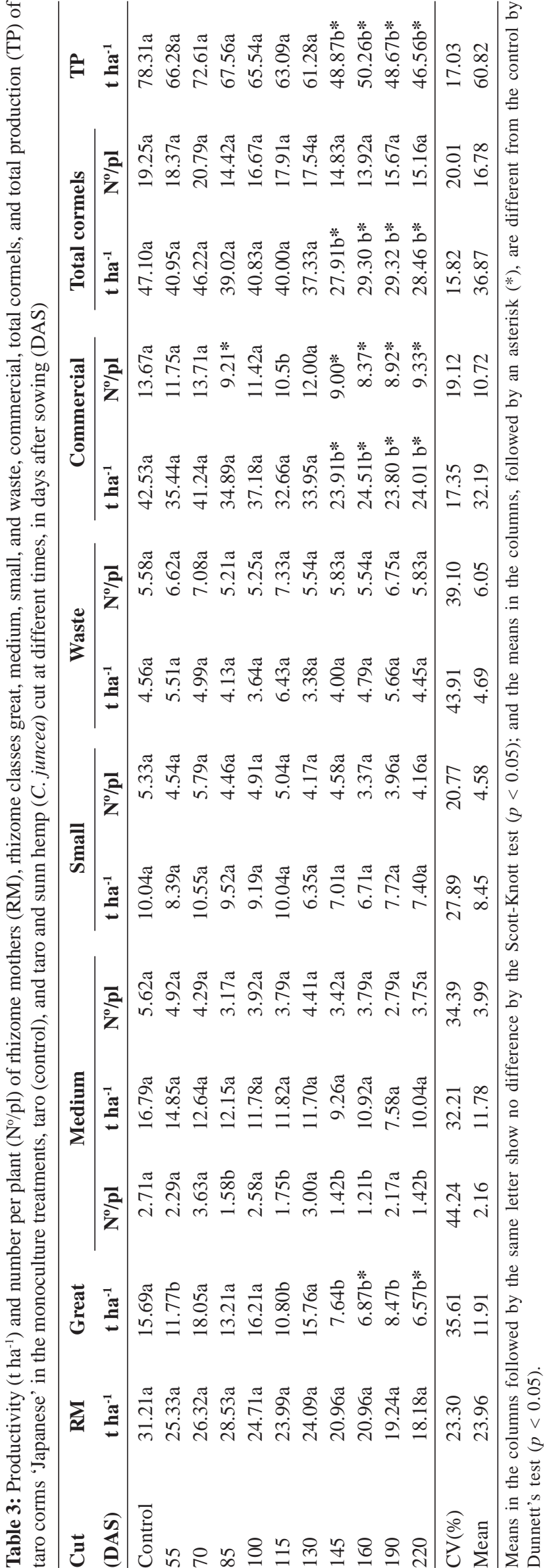

high amounts of all the nutrients evaluated. However, these nutrients, if available, were not likely used by taro as the leaf senescence process in taro had already begun. Leaf senescence is accompanied by the photosynthetic translocation from the shoot to the daughter rhizomes, which begins to occur at this developmental phase (Puiatti et al., 1992).

Although the smaller taro leaves experienced burn damage due to the cutting performed at 145 DAS, this benefit did not prevent that, in these treatments, the productivity of commercial daughter rhizomes, total daughter rhizomes, and total production rhizomes were damaged (Table 3). In addition to the absence of synchrony for the absorption of nutrients provided by the cut mass of sunn hemp, the light restriction caused by taro shading may have been excessive and/or the solar radiation may hve been deficient due to the high cloudiness that is normally observed in the region of Viçosa - MG, Brazil.

Under severe conditions of light restriction, taro plants showed better shoot growth and leaf area expansion at the expense of production of child rhizomes (Gondim et al., 2007; Oliveira et al., 2011). However, Gondim et al. (2007) and Oliveira et al. (2011) found that at 25 and $18 \%$ shading, respectively, their taro plants 'Chinese' and 'Japanese' did not change the growth patterns and nutrient accumulation, indicating that taro may benefit from intercropping, which provides moderate shading.

When sunn hemp is intercropped with taro as a method of providing nutrients to the soil without significantly affecting the yield of the commercial rhizomes, total cormels, and total productivity, cutting up to 130 DAS appears to be the most appropriate period. During this time, sunn hemp accumulates high amounts of biomass as well as macro and micronutrients. It is possible that the nutrient release of the cut sunn hemp coincides with the period of greatest nutrient absorption by the taro crop, without affecting the productivity of commercial daughter rhizomes. In addition, the residues which remain in the soil become a nutrient source for subsequent crops.

\section{Agroeconomic indicators}

The cutting of sunn hemp performed after 130 DAS affected the agroeconomic indexes of LUE, GI, NI, RR, and PI compared with the control and was below the average of the other treatments (Table 4). The LUE formed three groups, with the highest averages observed in the control treatment (the sunn hemp value was not considered) and the treatment of cutting hemp at 70 DAS, followed by the group formed by the cutting 
Table 4: Agroeconomic indicators: land use efficiency index (LUE); gross income; net income; monetary advantage (MA); corrected monetary advantage (CMA); rate of return (RR), and profitability index (PI) of the taro crops in the monoculture treatments of taro (control) and taro and sunn hemp (C. juncea) cut at different times, in days after sowing (DAS)

\begin{tabular}{|c|c|c|c|c|c|c|c|}
\hline \multirow{2}{*}{$\begin{array}{l}\text { Cut } \\
\text { (DAS) }\end{array}$} & LUE & Gross Income & Net Income & MA & CMA & \multirow{2}{*}{$\begin{array}{c}\text { RR } \\
\text { US\$/ US\$ }\end{array}$} & \multirow{2}{*}{$\begin{array}{c}\text { PI } \\
(\%)\end{array}$} \\
\hline & & & US\$ ha-1 & & & & \\
\hline Control & $1.00 \mathrm{a}$ & $16,707.37 \mathrm{a}$ & $12,020.94 a$ & 0.00 & 0.00 & $3.56 \mathrm{a}$ & $71.83 \mathrm{a}$ \\
\hline 55 & $0.83 b$ & $13,726.48 \mathrm{a}$ & $9,399.53 \mathrm{a}$ & $-1,957.24$ & $-1,270.32$ & $3.15 \mathrm{a}$ & $67.81 \mathrm{a}$ \\
\hline 70 & $0.96 a$ & $16,272.63 a$ & $11,598.55 a$ & -330.07 & -189.61 & $3.47 \mathrm{a}$ & $71.00 \mathrm{a}$ \\
\hline 85 & $0.78 b$ & $13,712.84 \mathrm{a}$ & $9,369.89 \mathrm{a}$ & $-2,984.40$ & $-2,032.22$ & $3.15 \mathrm{a}$ & $68.14 \mathrm{a}$ \\
\hline 100 & $0.87 b$ & $14,669.80 \mathrm{a}$ & $10,188.68 \mathrm{a}$ & $-1,831.06$ & $-1,264.76$ & $3.27 \mathrm{a}$ & $69.40 \mathrm{a}$ \\
\hline 115 & $0.77 b$ & $12,798.74 \mathrm{a}$ & $8,582.31 \mathrm{a}$ & $-2,879.36$ & $-1,912.93$ & $3.02 \mathrm{a}$ & $66.87 \mathrm{a}$ \\
\hline 130 & $0.80 \mathrm{~b}$ & $13,368.36 \mathrm{a}$ & $9,031.23 \mathrm{a}$ & $-2,616.76$ & $-1,756.76$ & $3.08 \mathrm{a}$ & $67.45 \mathrm{a}$ \\
\hline 145 & $0.56 \mathrm{c} *$ & $9,361.3 b^{*}$ & $5,549.12 b^{*}$ & $-3,143.61$ & $-1,585.96$ & $2.36 b^{*}$ & $53.52 \mathrm{~b} *$ \\
\hline 160 & $0.57 \mathrm{c} *$ & $9,571.56 b^{*}$ & $5,746.26 b^{*}$ & $-3,958.58$ & $-2,341.47$ & $2.48 b^{*}$ & $59.40 \mathrm{~b} *$ \\
\hline 190 & $0.56 c^{*}$ & $9,331.02 b^{*}$ & $5,511.97 b^{*}$ & $-4,078.63$ & $-2,395.76$ & $2.44 b^{*}$ & $58.80 \mathrm{~b} *$ \\
\hline 220 & $0.56 c^{*}$ & $9,370.82 b^{*}$ & $5,570.70 b^{*}$ & $-3,942.08$ & $-2,331.30$ & $2.45 b^{*}$ & $58.57 \mathrm{~b} *$ \\
\hline $\mathrm{CV}(\%)$ & 16.64 & 17.67 & 23.29 & - & - & 12.24 & 8.88 \\
\hline Mean & 0.75 & $12,626.45$ & $8,415.38$ & $-2,520.16$ & $-1,549.80$ & 2.95 & 64.80 \\
\hline
\end{tabular}

Means, in the columns, followed by at least one letter show no difference by the Scott-Knott test $(p<0.05)$; and the means in the columns, followed by an asterisk $(*)$ are different from the control by Dunnett's test $(p<0.05)$.

Dollar exchange rate: US\$ $1.00=\mathrm{R} \$ 4.0$

treatments at 55, 85, 100,115, and $130 \mathrm{DAS}$, and lastly, the group formed by the cutting treatments of 145 DAS onwards (Table 4).

The lowest values of the agroeconomic indicators were observed at the time of cutting performed at $145 \mathrm{DAS}$. It is possible that the reduced productivity of the commercial rhizomes was caused by cutting sunn hemp later than 145 DAS (Tables 3 and 4).

In all the treatments of the consortium, LUE was less than 1.0. From the agronomic and pragmatic perspective, it is assumed that both crops are suitable for intercropping as LUE is greater than 1.0 (Ajalla et al., 2009). However, LUE value alone is not sufficient to determine whether the consortium is advantageous. It is the income indicators that will define the viability. In this case, unlike the other consortia, the culture intercropped with taro (sunn hemp) was considered as being without commercial value. Thus, in interpreting these indicators, we considered the best consortia as those that provided higher rate.

Therefore, according to the agroeconomic indicators, the best intercropping system was observed when sunn hemp was cut at $130 \mathrm{DAS}$, but this treatment showed no significant difference in comparison with the control. However, it is the income indicators that will define whether the GI values, NI, RR, or PI were affected when sunn hemp was cut at 130 DAS. This indicates that up to this time, the sunn hemp legume may be adopted in association with taro cultures without any reduction in the economic profitability.

\section{CONCLUSIONS}

The taro and sunn hemp intercropping system is viable, both agronomically and economically, when sunn hemp is cut at 130 days after sowing.

Focusing only on the nutrient supply, cutting sunn hemp at 115 days after sowing provides greater contribution of $\mathrm{N}$ and $\mathrm{K}$ to the system without impairing commercial taro production.

\section{ACKNOWLEDGEMENTS}

We thank CNPq, CAPES, and FAPEMIG for the financial support.

\section{REFERENCES}

Ajalla ACA, Vieira MC, Zarate NAH, Mota JH \& Souza TM (2009) Produtividade da marcela [Achyrocline satureioides (lam.) DC.] em cultivo solteiro e consorciado com tansagem (Plantago major L.). Ciência e Agrotecnologia, 33:488-495.

CEASA - Centrais de abastecimento de Minas Gerais (2011). Lista Completa de Preços dos Produtos nas Unidades da CeasaMinas. Available at: 〈http://www.ceasaminas.com.br>. Accessed on: December $7^{\text {th }}, 2012$.

Cecílio filho AB, Costa CC, Rezende BLA \& Leeuwen R (2008) Viabilidade produtiva e econômica do consórcio entre chicória e rúcula em função da época de plantio. Horticultura Brasileira, 26:316-320.

Conab - Companhia Nacional de Abastecimento (2014) Programa de modernização do mercado brasileiro hortigranjeiros PROHORTE. Disponível em: <http://www3.ceasa.gov.br/ prohortweb>. Acessado em: 02 de janeiro de 2014. 
Gondim ARO, Puiatti M, Cecon PR \& Finger FL (2007) Crescimento, partição de fotoassimilados e produção de rizomas em taro cultivado sob sombreamento artificial. Horticultura Brasileira, 25:418-428.

Gondim ARO, Puiatti M, Ventrella MC \& Cecon PR (2008) Plasticidade anatômica da folha de taro cultivado sob diferentes condições de sombreamento. Bragantia, 67:1037-1045.

Hashad MN, Stino KR \& El Hinnawy SI (1956) Transformation and translocation of carbohydrates in taro plants during growth. Annals of Agricultural Sciences, 1:261-267.

Michereff SJ, Maffia LA \& Noronha MA (2000) Escala diagramática para a avaliação da severidade da queima das folhas do inhame. Fitopatologia Brasileira, 25:612-619.

Oliveira EQ, Bezerra Neto FB, Negreiros MZ, Barros Júnior AP, Freitas KKC, Silveira LM \& Lima JSS (2005) Produção e valor agroeconômico no consórcio entre cultivares de coentro e de alface. Horticultura Brasileira, 23:285-289.

Oliveira FL, Ribeiro RLD, Silva VV, Guerra JGM \& Almeida DL (2004) Desempenho do inhame (taro) em plantio direto e no consórcio com crotalaria, sob manejo orgânico. Horticultura Brasileira, 22:638-641.

Oliveira FL, Guerra JGM, Junqueira RM, Silva EE, Oliveira FF, Espindola JAA, Almeida DL, Ribeiro RLD \& Urquiaga S (2006) Crescimento e produtividade do inhame cultivado entre faixas de guandu em sistema orgânico. Horticultura Brasileira, 24:5358 .

Oliveira FL, Guerra JGM, Ribeiro RLD, Almeida DL, Silva EE, Urquiaga S \& Espindola JAA (2007) The use of sunn hemp as green manure intercropped with taro. Horticultura Brasileira, 25:562-566.

Oliveira FL, Araujo AP \& Guerra JGM (2011) Crescimento e acumulação de nutrientes em plantas de taro sob níveis de sombreamento artificial. Horticultura Brasileira, 29:291-298.

Pedralli G, Carmo CAS, Cereda M \& Puiatti M (2002) Uso de nomes populares para as espécies de Araceae e Dioscoreaceae no Brasil. Horticultura Brasileira, 20:530-532.

Puiatti M, Greeman S, Katsumoto R \& Favero C (1992) Crescimento e absorção de macronutrientes pelo inhame 'Chinês' e 'Japonês'. Horticultura Brasileira, 10:89-92.
Puiatti M, Fávero C, Finger FL \& Gomes JM (2000) Crescimento e produtividade de inhame e milho doce em cultivo associado. Horticultura Brasileira, 18:24-30.

Puiatti M (2002) Manejo da cultura do taro. In: Carmo CAS (Ed.) Inhame e taro: sistema de produção familiar. Vitória, INCAPER. p.203-254.

Puiatti M, Oliveira NLC, Cecon PR \& Bhering AS (2015) Consorciação de taro e crotalaria manejada com corte rente ao solo e poda na altura do dossel. Revista Ceres, 62:275-283.

Recope-RJ - Rede de Agroecologia do Estado do Rio de Janeiro (1999) Relatório trimestral, julho a setembro. Available at: <http://www.embrapa.br/agrobiologia>. Accessed on: January $2^{\text {th }}$, 2014.

Santos IC, Sediyama MAN \& Pedrosa MW (2013) Adubação verde no cultivo de hortaliças. Viçosa, EPAMIG. 6p. (Circular Técnica, 179).

Silva EE, De-Polli H, Guerra JGM, Azevedo PHS, Teixeira MG, Espindola JAA \& Almeida MMTB (2006) Consórcio de inhame (taro) e crotalaria em sistema orgânico de produção. Seropédica, Embrapa Agrobiologia. 4p. (Comunicado Técnico, 88).

Silva TO \& Menezes RSC (2007) Adubação orgânica da batata com esterco e, ou, Crotalaria juncea. II - Disponibilidade de N, $\mathrm{P}$ e K no solo ao longo do ciclo de cultivo. Revista Brasileira de Ciência do Solo, 31:51-61.

Siqueira RG, Santos RHS, Perigolo D, Urquiaga S, Ribas RGT \& Peternelli LA (2009) Nutrição nitrogenada e produção de brócolis cultivado com diferentes doses de mucuna em duas épocas. Revista Ceres, 56:826-833.

Souza JL \& Resende P (2006) Manual de horticultura orgânica. Viçosa, Editora Aprenda Fácil. 843p.

Taiz L \& Zeiger E (2010) Plant physiology. $5^{\text {th }}$ ed. Sunderland, Sinauer Associates. 782p.

Tivelli SW, Kano C, Purquerio LFV, Wutke EB \& Ishimurai I (2013) Desempenho do quiabeiro consorciado com adubos verdes eretos de porte baixo em dois sistemas de cultivo. Horticultura Brasileira, 31:483-488. 